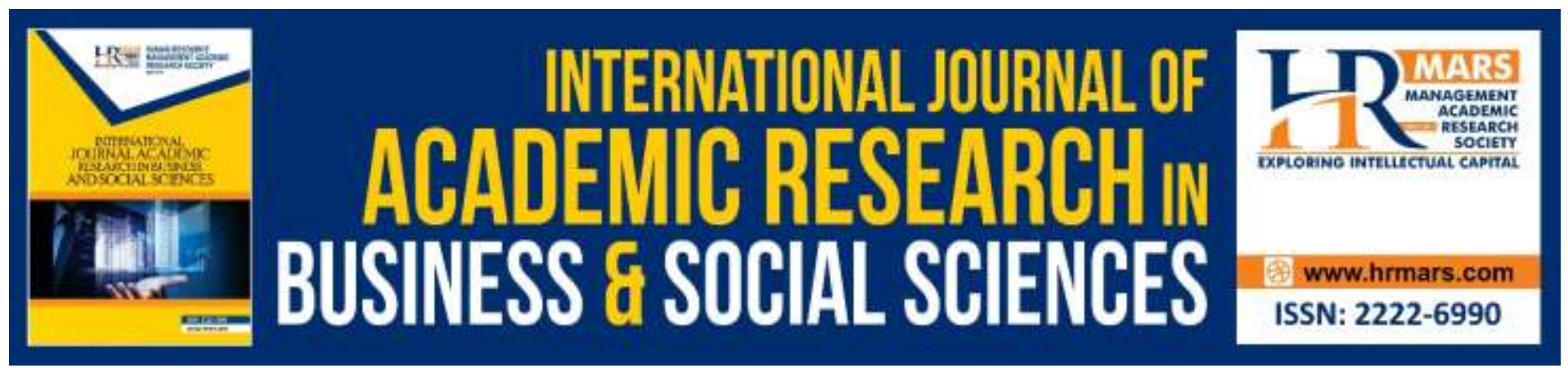

\title{
Causes and Ways to Overcome Bully among Students from National Primary Schools, National Type Chinese Primary Schools and National Type Tamil Primary Schools
}

Suppiah Nachiappan, Wong Kung Teck, Mohd Nazir Md Zabit, Sangkari Chandra Sehgar, Sandra Suffian, Noor Athirah Sukri

To Link this Article: http://dx.doi.org/10.6007/IJARBSS/v8-i8/4426

DOI: $10.6007 /$ IJARBSS/v8-i8/4426

Received: 24 June 2018, Revised: 12 July 2018, Accepted: 29 July 2018

Published Online: 13 August 2018

In-Text Citation: (Nachiappan et al., 2018)

To Cite this Article: Nachiappan, S., Teck, W. K., Zabit, M. N. M., Sehgar, S. C., Suffian, S., \& Sukri, N. A. (2018). Causes and Ways to Overcome Bully among Students from National Primary Schools, National Type Chinese Primary Schools and National Type Tamil Primary Schools. International Journal of Academic Research in Business and Social Sciences, 8(8), 1-11.

Copyright: @ 2018 The Author(s)

Published by Human Resource Management Academic Research Society (www.hrmars.com)

This article is published under the Creative Commons Attribution (CC BY 4.0) license. Anyone may reproduce, distribute, translate and create derivative works of this article (for both commercial and non-commercial purposes), subject to full attribution to the original publication and authors. The full terms of this license may be seen

at: http://creativecommons.org/licences/by/4.0/legalcode

Vol. 8, No. 8, August 2018, Pg. 1 - 11

Full Terms \& Conditions of access and use can be found at http://hrmars.com/index.php/pages/detail/publication-ethics 


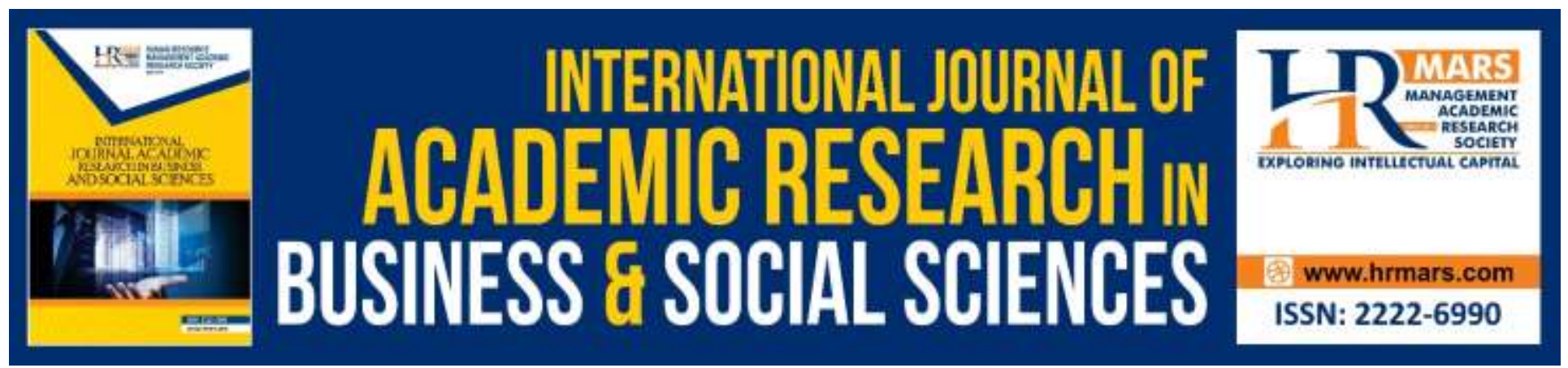

\title{
Causes and Ways to Overcome Bully among Students from National Primary Schools, National Type Chinese Primary Schools and National Type Tamil Primary Schools
}

\author{
Suppiah Nachiappan, Wong Kung Teck, Mohd Nazir Md Zabit, \\ Sangkari Chandra Sehgar, Sandra Suffian, Noor Athirah Sukri \\ Faculty of Human Development, Sultan Idris Education University \\ Email: suppiah@fpm.upsi.edu.my,thomas@fpm.upsi.edu.my,mohd.nazir@fpm.upsi.edu.my, \\ sangkarichandra@yahoo.com, sandrasuffian@gmail.com,noorathirah91@yahoo.com.
}

\begin{abstract}
The study aims to analyze the causes and ways to overcome bully among students from National Primary Schools, National Type Chinese Primary Schools and National Type Tamil Primary Schools. In addition, this study is also carried out with the aim of producing a guidebook to handle the symptoms of bullying that can help teachers in the management of pupils in the classroom. Qualitative approach with the Hermeneutics method has been used in this study. A total of 59 respondents were involved in this study. Respondents were selected among the primary school teachers in the district of Kinta Utara, Perak, which consisted of 20 teachers from National Primary Schools, 20 teachers from National Type Chinese Primary Schools and 19 teachers from National Type Tamil Primary Schools. The instrument used in this study is a questionnaire with four parts. Then, the collected data were analyzed using the Hermeneutical method. The results show that the main cause of the bullying phenomenon among primary school children was due to the student's own attitude and mass media influence. The best way to overcome bully is to provide counseling to students, appropriate punishment to bully offenders and to apply religious education as well as moral values. In addition, the main content to fit in the guidebook on handling bully is the ways to overcome bully, the punishment that should be given to bullies and the characteristics of bullies and bully victims. The implications of the study indicate that the use of guidebook on handling bully can help teachers in the management of students in the classroom and to overcome bully.
\end{abstract}

Keywords: Bully, Hermeneutics Method, National Primary Schools, National Type Chinese, Primary Schools, National Type Tamil Primary Schools.

Introduction

One of the thrusts in Malaysia's 2015-2025 Education Blueprint is to produce graduates who are knowledgeable, ethical, positive and civilized to become noble human beings. This is because they 
will be universal citizens with a Malaysian identity that stands out, always ready and willing to sacrifice for the harmony and well-being of families, communities, nations and the world. Hence, stakeholders should be sensitive to the social development of pupils since elementary school in order to achieve their goals in Malaysia's 2015-2025 Education Blueprint.

Nowadays, disciplinary problems are becoming familiar among students either from middle school or primary school. Disciplinary problems, especially bullying behavior among school children have become a global phenomenon. Kalaiarasi (2014) states that bully problems are not only happening in Malaysian schools but also in schools in developed countries such as the United States, England, Japan and Australia. According to Datuk Chong Sin Woon, Deputy Minister of Education II Malaysia (2017), bully in schools is still under control, at an average of 0.06 per cent per year. According to statistics, cases of bullying and gangsterism do not increase seriously, but this issue is always taken seriously.

Understanding about bully behavior among pupils is important in order to find appropriate methods or approaches to overcome this problem. Although research on bullying is increasing, most studies are from Western countries. The discovery may not be likened to Malaysians due to cultural differences. Studies on bully that are conducted locally only focus on bully in secondary schools. Thus, this study is focused on bully among primary school students. The results of this study will have an effect on preventing early signs of bullying towards the problem of bullying. At the end of the study, a guide book on bullying will be produced as a guide to teachers in student management.

\section{Problem Statement}

Today, the symptoms of malicious behaviour among students are increasingly rising and increasingly warm in the news titles of the press. This shows how important the immediate action of certain parties to ensure that these issues are not contagious and increase. Bully is a type of misconduct that can negatively affect emotional well-being and academic progress of students. Bully problems and bullying tendencies among students are among the global issues that need immediate attention. This is because students are easily influenced and at the same time they are still looking for their identity, ability and adaptability to the environment.

A study conducted by Fauziah (2004) shows that bully problems also occur among secondary school students in Malaysia. Bullying behavior among secondary school students is an issue that must be addressed by all parties involved with the welfare and safety of students. However, the problem of bullying behavior has also spread in the culture of elementary students at present. The problem of bullying behavior needs to be addressed and solved as fast as possible so that it is not a problem that can affect the academic and student development.

According to Zahidah et al. (2016), bullying is also common among students when they use streaming media such as social media and YouTube to spread messages, emails and videos as well as attempts to embarrass victims. However, blaming students for being involved with social problems will not solve this problem but we need to identify the sources and factors that affect widespread bullying problems. According to Norhayati and Suriati (2015), cyber bullying tends to bully by making videos with bullying messages so that they can become viral on social media sites. Among the murder cases described by Norhayati and Suriati (2015) are cases where victims are being attacked and beaten by active bullies in schools.

According to Salwani et al. (2009), bully cases among primary school students have become a common issue. Therefore, in this study besides discussing the bullying problem among primary school students, researchers will also point out the causes of bullying and ways to overcome them. Bullying 
INTERNATIONAL JOURNAL OF ACADEMIC RESEARCH IN BUSINESS AND SOCIAL SCIENCES

Vol. 8, No. 8, August 2018, E-ISSN: 2222-6990 @ 2018 HRMARS

is often said to take place in the classroom, field, corridor, hall, canteen, toilet as well as outside the school fence. There are many causes that contribute to this unhealthy behavior such as the influence of the environment and friends. The precautionary measures that are deemed appropriate by the school, parents and the community to curb this situation are also highlighted in this study. A comfortable and safe school environment is needed to generate the perfect teaching and learning process for school children.

\section{Literature Review \\ Concept of Bully}

In the 21st century teaching and learning classrooms, discipline problem among students is undeniable. The discipline problem is caused by the anti-social behaviour that leads to violence in school area related to the problem of bullying behaviour (Fortin, 2003). Bullying is serious because if it is left unsolved, it will be a 'disease' in a society that can contribute to criminal cases or deviant behaviour to the country. According to Rigby (1996) and Tattum (1988), bullying refers to a situation when a person or group of more dominant people repeatedly hurts others and makes a person under stress. Olweus (1994) explains that bullying occurs within a certain period of time, but the habit of bully has a different level of awareness of what the victim feels as a result of the bullying.

When viewed from a physical aspect, most bullies have a strong, strong and powerful body. However, from psychosocial aspects, often the bullying psychosocial stage is low (Demaray \& Malecki, 2003). Bullies are usually more aggressive, physically stronger and larger than prey. Based on the definition of bullying, it can be concluded that bullying is an abuse of power. This abuse refers to repetitive psychology or physical acts against weak individuals or individuals who are unable to defend themselves in the real situation by more powerful individuals or groups. This act is due to the will or desire to injure a person and may place the victim in a depressed situation.

\section{Types of Bully}

Quistgaard (2008) states that there are several types of bully, which are direct bully and indirect bully. The first type of bully is a physical bullying that refers to intentional behaviour that result in harm to the victim's body such as hitting, kicking, pushing or spitting on the victim. Secondly, emotional bullying will result in harm to the victim through the use of words used for the purpose of insulting the victim. Other examples of emotional bullying include contempt, harassment, mocking, threatening and contempt of ethnicity. The third type is the bullying of a relationship which is a direct or indirect act aimed at excluding or manipulating others intentionally. Culleton-Sen and Crick (2005) point out that the category of bullying is like cursing, spreading rumours, exceptions or denials of friends.

In today's technological development era, bully uses electronic equipment such as the use of computers, mobile phones and electronics to deceive others. The fourth type of cyber bullying involves both forms of bullying behaviour such as sending abusive or threatening messages and to make them look bad, spreading sensitive personal information to defame the victim or intentionally excluding victims of the online group (Willard, 2007). Unlike bullying face-to-face, cyber bullying can target victims at any time and for large audiences. Anonymity is associated with an electronic contact form to protect cyber bullying from restrictions and actions (http://www.stopbullying.gov). Cyber bullying like this will cause major problems if not blocked because through the rapid development of this technology can cause bullying problems. Furthermore, from the occurrence of this bully, witnesses of the incident will experience emotional disturbances, which is anxiety even though the 
INTERNATIONAL JOURNAL OF ACADEMIC RESEARCH IN BUSINESS AND SOCIAL SCIENCES

Vol. 8, No. 8, August 2018, E-ISSN: 2222-6990 @ 2018 HRMARS

habit of bullying will not endanger witnesses. This situation causes the witnesses to not make any complaints regarding the bullying incidents that have occurred.

\section{Factors Causing Bully}

It is not a simple matter to identify the occurrence of bully cases. This is because there are many angles to be seen as the aspects of family background, bully's and victim's personality, social status, school and peers who are so complex. Children who are often victims of bullying will often highlight the characteristics of internal behaviour such as being passive, sensitive, quiet, weak and will not respond if attacked or disturbed (Nansel et al., 2001). They also lack confidence and low self-esteem. Family factors, guardians and teachers are seen from the aspect of education. The use of extreme violence and actions used by parents in the discipline of children, guardians and teachers can indirectly encourage bullying in children (Stevens et al., 2002). Children who have less love, lack of perfect education and positive reinforcement will often become bully and be aggressive and more aggressive.

Peers also play an important role in the development and maintenance of bullying behaviour, anti-social behaviour and other misconduct among children (Herson \& Thomas, 2000). The presence of peers as an observer indirectly helps the bully gain power, popularity and status. The bully will feel more popular because the 'strength' has been witnessed by peers even though peers usually take the 'being quiet' step as witnesses of the incident. According to O'Connell, Pepler and Craig (1999), failure to act or report bully cases will ultimately reinforce the behaviour of bully and continue to allow bullying acts to be carried out indiscriminately. Husmiati and Fahrudin in their studies in 2013 state that in many cases, witnesses or peers who see, will generally be silent and do not want to intervene.

\section{Researches in Malaysia}

A study conducted by Fauziah (2004) shows us that bullying behaviour problems occur among Secondary School students in Malaysia. Bullying behaviour amongst secondary school students is an issue that must be addressed by all parties involved with the welfare and safety of students. Behavioural problems need to be solved as best as possible so that it is not a problem that can affect the academic and student development.

According to Yahaya, Ramli, Ahmad, and Muhammad (2007), the increase in the number of criminal incidents committed by school girls such as rape cases, free sex, gangsterism, bullying and murder have raised concern and concern for the whole community of the country. According to Yahaya et al. (2007), the change of behaviour can be influenced by various factors. Bully behaviour is not a behaviour that occurs naturally or is taught directly to children. Children exposed to the environment will be easily affected. Among the factors that can influence them evolve into bully include biological and behavioural factors, family influence, friends and environment. The role of parents and family backgrounds is also one of the factors that can influence a child to be aggressive in terms of their behaviour. Parents who often fight and act violently in front of children will give a very deep picture to the minds of children.

According to Al Haadi et al. (2013), in Malaysian school studies, bully victims feel inferior, sadly shy, because they are ridiculed so they feel less confident in themselves, easily offended (sensitive), moody, scared or dislike school. Al Haadi et al. (2013) in her study also found that bullying problems have led to a lack of healthy and unfriendly learning environment for those involved either bully, bully or bully. 


\section{Overseas Researches}

Olweus's early study on bully, in 1991 divided pupils into two types, namely bully and bully victims. Later, researchers have distributed bullying victims to two types, which are bullying victims and nonbullying victims. However, Olweus (2005) has classified victims into passive victims and provocative victims. A provocative victim refers to a bully victim who commits bullying to another student. They often interfere with other students even though they themselves are always bullied. His research also found that $6 \%$ of bullying victims were included in this category. They are less popular than bullies. They are also very angry, hyper-active, always feeling worried and defensive. Perry et al., (1988) has also put forward the same idea but using different terms, less aggressive victims and very aggressive victims.

Based on a study conducted in the United Kingdom by Smith and Sharp (1994), 10 percent of students surveyed reported that they were either rarely or often bullied throughout the study period. They also found that 4 percent of students surveyed reported that they had been bullied at least once a week. This finding shows that the level of bullying in primary schools is lower than secondary schools. The findings of this study are in parallel with studies conducted by other scholars such as Olweus (1993); Smith and Sharp (1994); and Rigby et al., (1997).

While, Collins et al., (2004) conducted a study in Northern Ireland and found otherwise that the percentage of primary school students being bullied by peers was higher than secondary school students. More small-minded male students are reportedly often victims of bullying and such incidents start from primary or primary school. It is also found that one in four low-school boys will be victims of bullying to either male or female bullies. In addition, bully victims typically do not have many friends (Rigby \& Slee, 1991). Comparisons by gender found that male students twice as likely to become bully victims compared to female students. In terms of age, the prey is usually younger. This statement is also supported in the study of Olweus (1991) which explains that about 11 percent of primary school children from two to sixth grade have been bullied and the youngest students are most at risk for being bullied.

\section{Research Objectives}

Generally, this study is conducted to analyse bully occurring in National Primary Schools, National Type Chinese Primary Schools and National Type Tamil Primary Schools. In particular, the objectives of this study are as follows:

i. Analyse the causes of bully among students from National Primary Schools, National Type Chinese Primary Schools and National Type Tamil Primary Schools.

ii. Analyse how to overcome bully among students from National Primary Schools, National Type Chinese Primary Schools and National Type Tamil Primary Schools.

iii. To produce guidebook to deal with bully that can help teachers in the management of students in classroom.

\section{Research Questions}

This research is carried out in order to answer the following questions:

i. What is the cause of bully among students from National Primary Schools, National Type Chinese Primary Schools and National Type Tamil Primary Schools? 
INTERNATIONAL JOURNAL OF ACADEMIC RESEARCH IN BUSINESS AND SOCIAL SCIENCES

Vol. 8, No. 8, August 2018, E-ISSN: 2222-6990 @ 2018 HRMARS

ii. What are the ways to overcome bully among students from National Primary Schools, National Type Chinese Primary Schools and National Type Tamil Primary Schools?

iii. How can the guidebook to deal with bully help teachers in the management of pupils in the classroom?

\section{Research Methodology}

This study uses descriptive qualitative method in the form of Hermeneutics method. This method is used to interpret the questionnaire text to study and analyse the factors and ways to overcome bully among primary school students. This method is also used in analysing content of guide book to deal with bully that can help teachers in the management of students in classroom. According to the Hermeneutical method, the questionnaire is the text and the result after interpreting the text is metatext. Meta text refers to a new clearer text created after understanding the text in depth. Meta text is the second text derived from the original text (Suppiah, 2016). In this study, the metatext is the result of the interpretation made on the questionnaire which contains an explanation of the meaning sought in the text.

\section{Research Outcome}

Cause of bully among students from National Primary Schools, National Type Chinese Primary Schools and National Type Tamil Primary Schools

Based on the findings, it is found that there are various causes that contribute to bullying behaviour among primary school children. The main cause identified is the attitude of the students involved. The attitude here includes jealousy and revenge towards friends. In addition, the lack of parents' concern for children is also a major cause of bully among primary school children. It cannot be denied that parents are the closest people to children because children spend a lot of time with parents at home. However, there are parents who do not pay attention to the changes in the behaviour of their children. This makes the children feel depressed because they do not get affection and become wild. According to Stevens et al. (2002), children who have no love and perfect attention will be more aggressive and likely to be a quick-tempered man.

At the same time, there are also students who become aggressive and bully other students by mimicking the behavior of aggressive parents. Stevens et al., (2002) also pointed out that the use of excessive violence and actions in disciplining children by parents, guardians and teachers can indirectly promote bullying in children. In addition, the findings showed that bully among primary school students is also due to lack of religious education. Sufficient religious studies will infuse the pure values of the students. When students do not get enough religious instruction, they will behave without thinking about the good and bad things.

Although the following are the main causes of bullying symptoms, there are also other causes that contribute to bullying behavior among primary school children such as peer influences, media influences and lack of knowledge on bully.

\section{Ways to overcome bully among students from National Primary Schools, National Type Chinese} Primary Schools and National Type Tamil Primary Schools

The main step suggested by the respondents is to provide counseling sessions to students involved in the bully. These counseling sessions should be designed by the school to treat the students involved in bully acts. On the other hand, bully among students can also be overcome by punishing students who have bullied other students. The punishment given should be in accordance with the 
mistakes made by the student. The findings were supported by Coleman (1990) through rational choice theory. Based on this theory, wrong doers will consider the punishment to be received and the fun that will be accepted when doing something wrong. If the punishment received is heavier than the pleasures received, then the individual will not make the mistake. Thus, in this aspect of the study, students will refrain from committing bully if severe punishment is given.

Religious studies and the application of moral values in students can also help to overcome bully among primary school children. This statement was also supported by Fauziah (2004) in her study stating that at the individual level, the students should apply moral values based on religious and moral education to overcome bully among the students.

\section{Content of guidebook to deal with bully that can help teachers in the management of pupils in the classroom}

The findings of this study have found that some important aspects should be emphasized in the process of producing the guide book to overcome bully that can help teachers in the management of students in classroom. This guide book can be used by teachers at any time to overcome bully in their schools. Based on the answers given by teachers in the questionnaires, it is found that the measures to overcome bully are the main aspects that need to be incorporated in the guide book produced.

In addition, characteristics of bullies and bully victims should also be included in the generated guide book. These features will help teachers to detect students involved in bully acts. At the same time, students who are likely to be involved in bullying can also be identified by the teacher. This will help teachers to detect bully cases in school and try to overcome them before they become serious.

Furthermore, some programs that can help to overcome bully among primary school students can also be suggested in this guide book. The suggested programs can be used by teachers and the school administration to be implemented in their schools. By implementing different programs, teachers can attract students to things that are more beneficial.

Furthermore, the supports that students can get if they are bullied and ways to save themselves from being bullied will also be discussed in this guidebook. This will enable the victim to save himself when bullied. Overall, the content contained in this guide book does not only help teachers to solve bully problems among students but also help students to choose the appropriate steps to take if they are bullied. Thus, this guidebook can help teachers in student management in the classroom.

\section{Conclusion}

This study was conducted as a small effort to contribute to the field of education by explaining the causes of bully and the measures to overcome this problem among primary school children. Through this study, answers from 59 respondents on several suggestions to overcome bully among National Primary School students, National Type Chinese Primary School students and National Type Tamil Primary School students in Kinta Utara, Perak has been analysed. The proposed measures require cooperation of the school administration, teachers, parents and students themselves.

This study also explains the overall bully act including types of bully, characteristics of bullies and bully victims, the causes of bully as well as the steps to overcome bully. Thus, the content of this study can be used by readers, especially teachers, school administration, parents and students to gain knowledge about bully act that occur in primary schools. This knowledge can be used by parents and teachers to monitor the behaviour of their children so that they do not engage in bully acts. 
INTERNATIONAL JOURNAL OF ACADEMIC RESEARCH IN BUSINESS AND SOCIAL SCIENCES

Vol. 8, No. 8, August 2018, E-ISSN: 2222-6990 @ 2018 HRMARS

\section{Acknowledgement}

The author wish to thank Sultan Idris Educational University for financial support through the University Research Grant (code: 2017-0283-107-01) and Human Resource Department of Sultan Idris Education University. The author would also like to thank the Malaysian Education Ministry for allowing us to carry the survey in schools.

\section{Corresponding Author}

Suppiah Nachiappan

Faculty of Human Development,

Sultan Idris Education University, Tanjung Malim, Perak, Malaysia

Email: suppiah@fpm.upsi.edu.my

\section{References}

Coleman, J. (1990). Foundations of Social Theory. Cambridge, MA: Belknap Press of Harvard University Press.

Collins, K., Gerry, M., \& Gary, A. (2004). Bullying in School: A Nothern Ireland Study. Educational Research, 48(1), 55- 69.

Cullerton-Sen, C., \& Crick, N. R. (2005). Understanding the Effects of Physical and Relational Victimization: The Utility of Multiple Perspectives in Predicting Social-Emotional Adjustment. School Psychology Review, 34(2), 147-160.

Demaray, M. K., \& Malecki, C. K. (2003). Perceptions of the Frequency and Importance of Social Support by Students Classified as victims, Bullies, and Bully/Victims in an Urban Middle School. School Psychology Review, 32, 471- 489.

Ghani, N. M., \& Ghazali, S. (2015). Response of YouTube users on Bullying Cases Among Malaysian Students. Sains Humanika, 6(1), 9-17.

Kalaiarasi. (2014). Masalah buli dalam kalangan remaja di Malaysia. Bangi: Universiti Kebangsaan Malaysia. (Project Paper).

Kementerian Pendidikan Malaysia. (2015). Pelan Pembangunan Pendidikan Malaysia 2015 -2025 (Pendidikan Tinggi). Putrajaya: KPM.

Laurier, F. (2003). Students' antisocial and aggressive behavior: development and prediction. Journal of Educational Administration, 41(6), 669-688.

Nachiappan, S. (2016). Kaedah Hermeneutik: Kaedah Interpretasi Teks Secara Kualitatif. Tanjung Malim: Penerbit Universiti Pendidikan Sultan Idris.

Nansel, T. R., Overpeck, M., Pilla, R. S., Ruan, W. J., Simons-Morton, B., \& Scheidt, P. (2001). Bullying behaviors among US youth: Prevalence and association with psychosocial adjustment. Jama, 285(16), 2094-2100.

O'Connell, P., Pepler, D., \& Craig, W. (1999). Peer involvement in bullying: insights and challenges for intervention. Journal of adolescence, 22(4), 437-452.

Olweus, D. (1991). Bully/victim problems among school children: basic facts and effects of a schoolbased Intervention programme. In D. Pepler \& K. Rubin, (Eds.) The Development and Treatment of Childhood Aggression. Hillsdale, NJ: Erlbaum.

Olweus, D. (1993). Bullying in School. Oxford: Blackwell.

Olweus, D. (1994). Bullying at school: basic facts and effects of a school based intervention program. Child Psychology Psychiatry, 35, 1171-90. 
INTERNATIONAL JOURNAL OF ACADEMIC RESEARCH IN BUSINESS AND SOCIAL SCIENCES

Vol. 8, No. 8, August 2018, E-ISSN: 2222-6990 @ 2018 HRMARS

Olweus, D. (2005). A useful evaluation design and effects of the Olweus Bullying Prevention Program. Psychology, Crime \& Law, 11(4), 389-402.

Perry, D. G., Kusel, S. I., \& Perry, L. C. (1988). Victims of peer aggression. Development Psychology, 24, 807-814.

Quistgaard, P. (2008). Bullying in schools: understanding bullying and how to intervene with schools. IUC School of Social Work Theory and Practice, 18. Retrieved from http://www.bemidjistate.edu/academics/publications/social_work_journal/issue18/article 6.html

Rigby, K. (1994). School bullies. Independent Teacher, 4, 89.

Rigby, K., \& Slee, P. T. (1991). Bullying among Australian school children: Reported behaviour and attitudes towards victims. Journal of Social Psychology, 131, 615-627.

Rigby, K., Cox, I., \& Black, G. (1997). Cooperativeness and bully/victim problems among Austrialian school children. The Journal of Social Psychology, 137, 357-368.

Salwani, W., Tan, S. M. K., Ruzyanei, N., Iryani, T., Syamsul, S., Aniza, A., \& Zasmani, S. (2009). School Bullying Amongst Standard Six Students Attending Primary National Schools in the Federal Territory of Kuala Lumpur: the Prevalence and Associated Socio Demographic Factors. Malaysian Journal of Psychiatry, 18(1), 1-8.

Smith, G. (1997). The Safer Schools-Safer Cities Bullying Project. In Tattum, D., \& Herber, G. (Eds.). Bullying: home, school, and community. London: David Fulton Publisher.

Smith, P., \& Sharp, S. (1994). The problem of school bullying. In P.K. Smith \& S. Sharp (Eds.) School Bullying Insights and Perspectives. London:Routledge.

Stevens V., Bourdeaudhuij I. D., \& Oost P. V. (2002). Relationship of the family environment to children's involvement in bully/victim problems at school. Journal of Youth and Adolescence, 31(6), 419-428.

Tattum, D. (1988). Violence and aggression in schools. In D. Tattum and D. Lane. (eds). Bullying in schools. Stoke-on-Trent: Trentham Books.

Verlinden, S., Herson, M., \& Thomas, J. (2000). Risk factors in school shootings. Clinical Psychology Review, 20, 3-56.

Willard, N. E. (2007). Cyberbullying and cyberthreats: Responding to the challenge of online social aggression, threats, and distress. Champaign: Research Press.

Yaakub N. M. (2004). Insiden Buli di Kalangan Pelajar Sekolah Menengah: Implikasi Kepada Pengurusan Sekolah. Kertas Kerja Seminar Nasional Pengurusan dan Kepimpinan Pendidikan ke-11 di Universiti Malaya.

Yusuf, H., \& Fahrudin, A. (2012). Perilaku Bullying: Asesmen Multidimensi dan Intervensi Sosial. Jurnal Psikologi, 11(2), 10.

Zahidah, M. Z., Abdul, R. A., \& Mohd, M. A. (2016). Features of Active School Bullies. International Conference on Education and Regional Development (ICERD), Indonesia. 